\title{
Design process dynamics in an experience-based context : a design methodological analysis of the Brabantia corkscrew development
}

Citation for published version (APA):

Vries, de, M. J. (1994). Design process dynamics in an experience-based context : a design methodological analysis of the Brabantia corkscrew development. Technovation, 14(7), 437-448. https://doi.org/10.1016/01664972(94)90002-7

DOI:

10.1016/0166-4972(94)90002-7

Document status and date:

Published: 01/01/1994

Document Version:

Publisher's PDF, also known as Version of Record (includes final page, issue and volume numbers)

Please check the document version of this publication:

- A submitted manuscript is the version of the article upon submission and before peer-review. There can be important differences between the submitted version and the official published version of record. People interested in the research are advised to contact the author for the final version of the publication, or visit the $\mathrm{DOI}$ to the publisher's website.

- The final author version and the galley proof are versions of the publication after peer review.

- The final published version features the final layout of the paper including the volume, issue and page numbers.

Link to publication

\footnotetext{
General rights

- You may freely distribute the URL identifying the publication in the public portal. follow below link for the End User Agreement:

www.tue.nl/taverne

Take down policy

If you believe that this document breaches copyright please contact us at:

openaccess@tue.nl

providing details and we will investigate your claim.
}

Copyright and moral rights for the publications made accessible in the public portal are retained by the authors and/or other copyright owners and it is a condition of accessing publications that users recognise and abide by the legal requirements associated with these rights.

- Users may download and print one copy of any publication from the public portal for the purpose of private study or research.

- You may not further distribute the material or use it for any profit-making activity or commercial gain

If the publication is distributed under the terms of Article 25fa of the Dutch Copyright Act, indicated by the "Taverne" license above, please 


\title{
Design process dynamics in an
} experience-based context: a design methodological analysis of the Brabantia corkscrew development

\author{
Marc J. de Vries \\ Eindhoven University of Technology, The Netherlands
}

\begin{abstract}
In design methodology, the influence of various factors on design processes is studied. In this article the design of the Brabantia corkscrew is presented as a case study in which these factors are analysed. The aim of the analysis is to gain insight into the way Brabantia took these factors into account in the development of its corkscrew. This insight helps us to understand the success of the corkscrew.

An important step in the design process was the search for a solution to a problem with a juridical factor: there was a new patent for a competitive corkscrew on the UK market. In an experience-based approach, a new design was developed that avoided infringement of this patent and thus enabled Brabantia to reach a new favourable combination of technological, market, juridical and aesthetic characteristics in its corkscrew design. The way Brabantia originally designed the corkscrew and later changed that design presents an example of what can be called 'piecemeal rationality' (this concept is explained in the paper).

The article first describes the setting in which the design process took place (Section 1). Then the design methodological focus of the case study is presented (Section 2). Next an analysis of the design process before the patent problem emerged is given in Section 3. The search for a new design was led by a juridical analysis of the patent claims, and this process is described in Section 4. Finally, conclusions are drawn with respect to the question of whether Brabantia's corkscrew design process can be seen as an example of piecemeal rationality (Section 5).
\end{abstract}

\section{The corkscrew as an element in the Brabantia product range}

In 1985, the Dutch metal-processing firm Brabantia ${ }^{1}$ brought out a new corkscrew as part of a serics of kitchen gadgets. The product was an immediate success on the Dutch and German markets. It needed less force than many other corkscrews, had a good appearance and sold for a fair price (about Dfl 20.00 on the Dutch market).

There are three types of product in the Brabantia product range [1]: (1) gadgets of plastic and steel for food preparation; (2) cans and tins made out of steel such as breadbins, spaghetti tubes and 
biscuit tins; (3) products made of tubular steel, such as ironing tables and drying frames. Each of the three types generates about one-third of the Brabantia Group's total turnover. The first type, to which the corkscrew belongs, has only been part of the product range since 1976, when Brabantia had already existed for several decades (it was founded in 1919). In this year Brabantia decided to start developing a set of kitchen gadgets, one of which would be a corkscrew.

In general, Brabantia's policy for product development has the following characteristics [2]:

- the company aims at improving existing products rather than designing completely new ones;

- in the development process there are meetings between the management and the design group when important design decisions are taken;

- during the process there are also contacts between the design group and the production group, because all products are for mass production and therefore have to be designed in such a way that they can be produced in bulk (and since 1987 this has been formalized by using design for assembly (DFA) methods [3]);

- at the beginning of a development process, a patent search is done which is coordinated by C.H.J. van Elderen, who is Managing Director of the Brabantia Group ${ }^{2}$.

\section{The focus of the design methodological analysis of the Brabantia corkscrew}

To understand the rationale of the Brabantia corkscrew development process, we will use an analysis approach that describes the influence of scientific (S), technological (Te), market (M), political/juridical $(\mathrm{P} / \mathrm{J})$ and aesthetic $(\mathrm{E})$ factors. This approach, known as STeMPJE [4], was previously used to analyse the Philips Plumbicon (a television camera pickup tube) [5] and the Philips Stirling engine [6] developments ${ }^{3}$. These analyses led to the concept of 'piecemeal rationality': management decisions on design are guided by a combination of the factors mentioned above, and as this combination evolves during the history of a design, so do the requirements that the design must satisfy. The way new solutions that fit the requirements are developed differs for different types of technologies. In the STeMPJE approach, experience-based technologies, macrotechnologies and microtechnologies are distinguished ${ }^{4}$. The scientific knowledge that was used in developing the corkscrew is limited to mechanical knowledge derived directly from design experience. This means that the corkscrew is an example of an experience-based technology.

The focus of this article can now be stated in terms of the following questions. How did Brabantia take into account the dynamics of the scientific, technological, market, political/juridical and aesthetic factors in its design management decisions with respect to the corkscrew development? Is there a 'piecemeal rationality's in the way Brabantia responded to changes in the combination of these factors? From Brabantia's own description of their product development policy (see Section 1), one could expect the answer to the second question to be that the search for potentially successful designs can be adapted to the current situation with respect to market, production and existing patents etc., and conforms well to the idea of piecemeal rationality.

The data on which the article is based were to a large extent derived from the affidavits of the various participants in the Hallen vs. Brabantia juridical case. This juridical process forced Brabantia to make explicit the development processes and management decisions that led to the corkscrew.

\section{Corkscrew development previous to the conflict with the Hallen Company}

Corkscrews have been designed for a very long time. The first patent was granted in 1795 to Samuel Henshall. Since then, various types of corkscrew have been patented: the simple $T$ model, the lever type, the rack-and-pinion type, the flying nut design, and the corkscrews that are 
based on the self-puller principle ${ }^{6}$. Each of these types gives a different answer to the question of how the force that is needed to extract the cork can be reduced. Most corkscrew designs have a helix that is driven into the cork to allow the pulling force to be applied to the cork ${ }^{7}$.

After Brabantia had taken the decision to develop a corkscrew as part of its new kitchen set, research was carried out among customers to find out what requirements had to be met. It appeared that the following aspects would be important to consumers [1]: the presence of a foil cutter, a minimum of force to extract the cork (this to enable women to use the corkscrew), and the ability to remove the cork from the corkscrew without touching it (to prevent getting wine from the cork on one's hands). Brabantia already had some experience with designing corkscrews. M.P. Verhoeven, who had been educated as a product designer and had joined Brabantia in 1965, had produced a survey study on the various types of corkscrew that already existed, a procedure that fitted well with Brabantia's general product development policy to improve good existing ideas.

During this study, Verhoeven found at least four corkscrews of the self-puller type. It is a characteristic of this type of corkscrew that the insertion of the helix into the cork and the extraction of the cork are performed in one continuous motion. When the helix has been inserted into the cork completely, a stop prevents further downward motion of the helix and the continued turning of the helix then forces the cork to climb up the helix and it is thus extracted from the neck of the bottle. At that time, however, Verhoeven had a preference for a different type with a rack-and-pinion operation. In 1971 he had made a design for a corkscrew of that type, but at that time it had not been taken into production. In 1972 his colleague Wiericks was made responsible for corkscrew development because Verhoeven had been moved to other projects. In the years 1976-1982, several sessions were held to discuss what type of corkscrew would fit in the kitchen set. Verhoeven was sometimes involved in these because of his previous interest in cork- screws. In 1978, in one of the brainstorming sessions, he mentioned a self-puller corkscrew from the Sieger company. In 1982 Wiericks came up with a design of his own that worked with two parallel helices which were rotated simultaneously by turning a handle. Wiericks expected this design to be successful, because it gave more grip on the cork, was better at preventing the cork from breaking, and allowed the cork to be removed from the helices without touching it. The helices would be coated with PTFE (polytetrafluoroethylene), a friction-reducing material, that so far had not been used on commercial corkscrews but was known from other applications, e.g. screws, nuts and bolts. An effort was made to get the double helix design patented in July 1982, but without success. The design was found to function well, according to colleagues who had used it at home. The construction, however, was extremely complicated and in use there was the possibility of damaging the helices by rotating the whole corkscrew. Therefore it was decided to abandon the idea shortly after Wiericks retired in 1982 (which strongly suggests that the double helix design was Wierick's personal hobby horse). At that time, Verhoeven again took over the corkscrew development project and came across a model of the self-puller type named the Screwpull. It was sold by the Hallen company, and the product functioned quite satisfactorily, although Verhoeven noticed several aspects that could be substantially improved. One of the attractive properties it had was the PTFE coating on the helix, which Verhoeven had never seen on a corkscrew that was already on the market (Wiericks' model also had such a coating, but that had never been produced). A patent search was carried out and no patent was found (it later emerged that the Hallen patent for this corkscrew was just about to be published). Verhoeven started working on the following improvements ${ }^{2}$ [2]:

- the Brabantia corkscrew would be in one piece instead of having a separate helix as in the Screwpull;

- the sharp point of the helix would be protected in a closed body; 
- a foil cutter would be added;

- a cork ejecting device would be added;

- it would be designed to stand, hang or lie (e.g. in a drawer);

- the overall shape of the Wiericks design would be kept to make it fit in with the kitchen gadget set.

It is clear that this list reflects the various factors we mentioned earlier: it used the phenomena of the self-puller principle and the friction-reducing property of the PTFE coating (both examples of experience-based technology), it took into account both market and aesthetic demands (the requirement of a foil cutter and the cork-ejecting device that had come forward in the market research, and the requirement that the appearance had to fit with the other elements of the kitchen set) and the company had looked for existing patents to avoid infringement (the juridical factor). The combination of these factors appeared to be favourable because the proposed changes to the Screwpull would result in a completely new design. Here we can see how Brabantia took a step in the development of its corkscrew that seemed to fit best with the various factors as the company perceived them at that time.

The requirements mentioned above led to fairly dramatic changes in the appearance of the corkscrew compared with the Screwpull (the appearance was dominated by the cylinder by which the helix was surrounded). In 1983, Verhoeven had succeeded in making the necessary adaptations (the result is shown in Fig. 1) and the corkscrew was put into production in 1985. A major problem in production was the coating: it wore off too quickly. However, as the Screwpull had the same problem, it was decided to continue production and meanwhile look for a better solution. This was found in 1987 at an International Fair in Frankfurt, and was a coating made of hard nickel with PTFE particles in it. It was found to hold well on the corkscrew helix, and when the Cruson factory, which had produced the PTFE coating for Brabantia since 1984, was burned down in 1987 , it was decided to switch over to the new

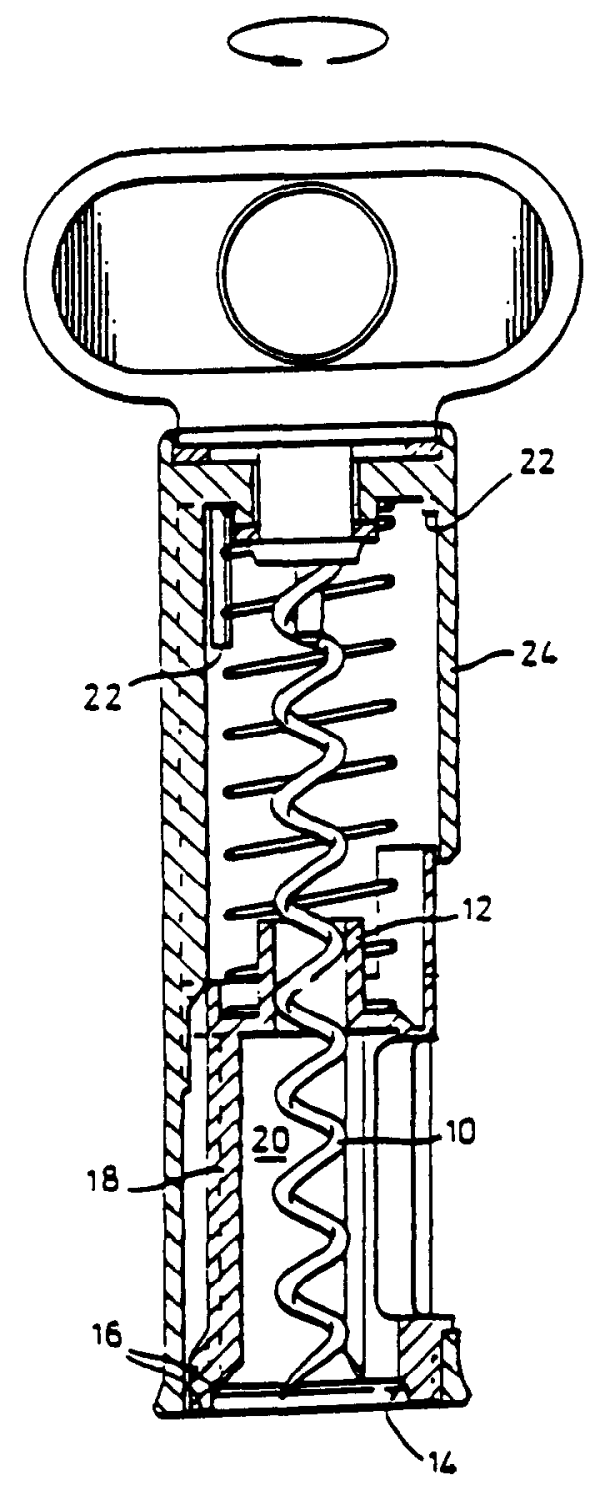

Fig. 1. The original Brabantia corkscrew design.

nickel/PTFE coating. Another production problem was the sharpening of the helix point. Finally, a company in Switzerland was found that was able to make the point sharp enough to fit Brabantia's requirements.

The Brabantia corkscew was launched at the Frankfurt Spring Fair in 1985. In the same year it 
won a design award at the Utrecht Spring Fair. The corkscrew was sold on the Dutch and German markets. In February 1987 it was presented at the Exclusive Housewares Fair in the United Kingdom. It had already been noticed at one of the earlier fairs by the firm that marketed the Hallen Screwpull, and a letter had been sent to Brabantia UK by Simmons and Simmons, Hallen's patent agents, to warn Brabantia of possible infringement of the Hallen patent if the Brabantia corkscrew was ever sold on the UK market ${ }^{8}$. On advice of Bristows, Cooke and Carpmael, Brabantia's patent agents, the introduction of the corkscrew onto the UK market still took place because it was expected that the validity of the Hallen patent could be disputed. Thus, the juridical factor was still estimated to be favourable for the Brabantia corkscrew. However, this factor later appeared to be more problematic and ambivalent than had been expected. If Brabantia had known beforehand what the result of the process would be, the firm might have made its design change earlier. This shows that the rationality of the corkscrew development was not once-and-for-all but piecemeal: Brabantia made the design fit the factors as they were perceived at the time. Later, when the juridical factor changed in the sense that the Hallen patent appeared to be a problem for the Brabantia corkscrew, the design was adapted to make it fit the new situation.

\section{Brabantia's response to the juridical challenge}

As an analysis of the juridical factor in this phase of the design process of the Brabantia corkscrew is crucial for an analysis of the design methodology used when Brabantia took the next step to a successful design, an extensive description of the examination of the claims involved will be given.

From a juridical point of view the patent situation was unusual for the Dutch board of managers because of the differences between the Dutch and UK patent systems. In the Netherlands, as, e.g., in Germany, a full examination for novelty is required for a patent to be accepted. In the UK, however, this examination is only carried out if the novelty of the patent is challenged [10]. This means that consideration of this J-factor in Brabantia's decision-making is a complicated one: there was a comparatively high degree of uncertainty about the validity of the Hallen corkscrew patent because it had not yet been challenged, and therefore it had never been examined with respect to its novelty.

On 26 February 1987, a 'Writ of Summons' was issued against Brabantia UK, followed by the 'Particulars of Infringement' on 13 March 1987. Herein, Brabantia was accused of infringing Claims $1-4,8-11$ and 13 of Patent No. UK 2027681 (Hallen's Screwpull patent). The defendants responded by a counterclaim on 21 March 1987, wherein they requested rejection of the patent because of the obviousness of the invention.

The case was dealt with by Judge Falconer. P.C. Allam, who represented Hallen's patent agent, stated for the judge that Brabantia's corkscrew had the following elements in common with the Screwpull: the coated helix, the guide means, the bottle engaging means, the stop means, the spacer means, the opening for the helix, the abutment means and the open space that receives the cork [11]. ${ }^{9}$ Even in this early stage of the process it had become evident that the coating of the helix was a crucial element of the patent, and this element was immediately attacked by J.R.A.M. Cheyne, who represented Brabantia's patent agent. He pointed out that the patent explicitly mentioned that the bottom side of the helix would be coated but not the upper side. This suggests that the relevance of the coating was only seen in the reduction of friction during the downward movement of the helix and not during the upward movement of the cork [12]. This issue was taken up several times in later stages of the process.

On 3 June of the same year, Judge Falconer decided that this matter was a triable issue, and then a juridical discussion started in which Judge Aldous had to weigh the various arguments of Hallen and Brabantia. 
An analysis of the claims showed that the main issue to be judged was as follows: three of the claims (Nos 1, 2 and 3) in the Hallen patent had to be examined for infringement by Brabantia's corkscrew design, and six of the claims (Nos. 1, $2,3,8,9$ and 10) had to be examined for validity [13]. The defendants had admitted that if Claim 1 was infringed so were Claims 4, 8, 9, 10, 11 and 13 , because these claims merely described some details about the elements of the corkscrew that had been listed in Claim 1. The plaintiffs had accepted that if Claim 1 was invalid, Claims 4,11 and 13 could not add to its validity because they only contained elaborations of the first claim.

As the literal text of the claims in a juridical discussion is quite important, the full text will now be quoted and then the meaning of the claims will be explained with reference to the patent drawings.

The claims read as follows:

1. Apparatus for extracting a cork from a bottle comprising:

- a corkscrew comprising a helical body and an outer layer of friction reducing material;

- guide means receiving said corkscrew and permitting longitudinal and rotational movement of said corkscrew;

- bottle engaging means connected to said guide means for positioning said guide means and said corkscrew in generally coaxial alignment with the neck of said bottle, said bottle-engaging means including stop means for limiting downward (as hereinbefore defined) movement of said guide means with respect to said bottle;

- spacer means interconnecting said guide means and said bottle-engaging means and spacing said guide means upwardly (as hereinbefore defined) from said bottle-engaging means, said spacer means defining an opening for receipt of said cork as it emerges from said bottle;

- and abutment means carried by said corkscrew for limiting downward (as hereinbefore defined) movement of said corkscrew with respect to said guide means;

- said corkscrew being a length such that, when said abutment means are engaged to so limit downward (as hereinbefore defined) movement of said corkscew, said corkscrew extends into said cork-receiving opening whereby said cork may move threadedly upwardly (as hereinbefore defined) on said corkscrew as said corkscrew is rotated to withdraw said cork from said bottle.

2. Apparatus according to Claim 1, wherein said friction-reducing material is a plastics coating bonded to said helical body.

3. Apparatus according to Claim 2, wherein said friction-reducing material is a polytetrafluoroethylene.

8. Apparatus according to any preceding claim, wherein said helical body is formed of a wire wound into a helical configuration.

9. Apparatus according to any preceding claim, wherein said guide means has a guide passageway extending generally longitudinally therethrough and having generally radially facing guide surface means, the helical body of said corkscrew having a diameter sized to lie closely adjacent to said guide surface means.

10. Apparatus according to Claim 9, wherein said guide passageway has a length at least as long as the pitch of the helix of said corkscrew.

The patent drawing in Fig. 2 shows the various elements that are mentioned in these claims. The corkscrew has a main body (10) with two legs (12) that are to be put on the neck of the bottle (22). The handle (20) is inserted through the guide means (14). By turning the handle, the helix (18) is inserted into the cork (24). This downward movement is stopped when the abutment of the hub (20) touches the bushing (16). By turning further in the same direction, the user forces the cork to climb upward on the helix. The cork then comes into the space enclosed by (12a) and lifting up the holder removes the cork from the bottle.

A series of hearings was held before Judge Aldous, in which both plaintiffs and defendants brought forward their points. Some sessions were aimed at testing the various types of corkscrews that were mentioned in the affidavits: the Screwpull and the Brabantia corkscrew, but also some uncoated corkscrews of the self-puller type to investigate the relevance of the coating, and also some coated corkscrews of other types. The judge himself opened several bottles of wine with these corkscrews and also listened to the opinion of some experts on wine and corkscrews. The contents 
FIG. 1

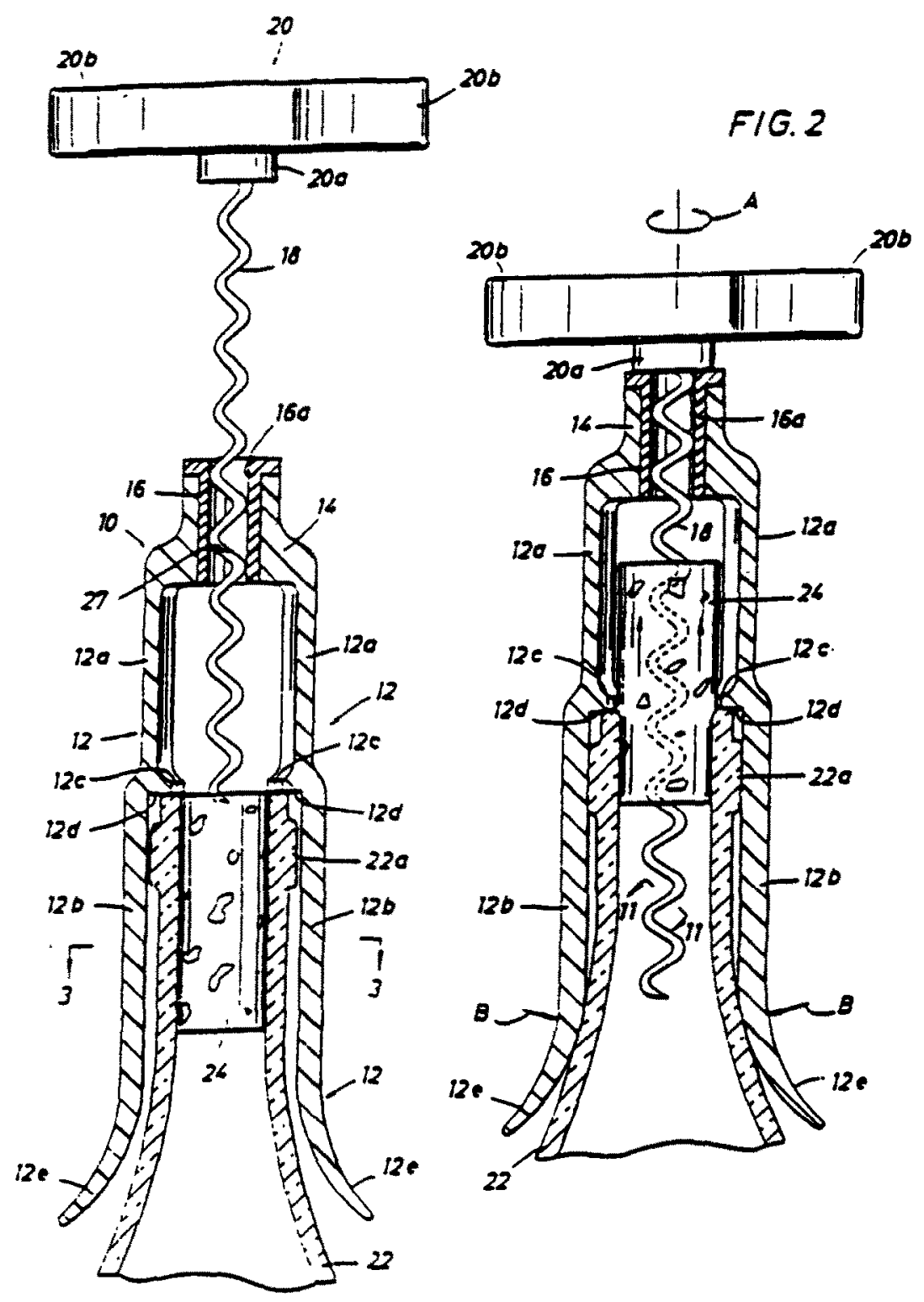

Fig. 2. The Hallen Screwpull design.

of the hearings are now summarized by describing the judge's deliberations, which led to his final judgement on 2 October 1988.

With respect to Claim 1 , it soon became evident that this claim was infringed, although Brabantia tried to raise the issue of whether or not the abutment means were 'carried by' the corkscrew in the Brabantia design (the judge found this to 
be word-play only). Claims 2 and 3 were also found to be infringed. Here Brabantia tried to bring forward the argument that the coating of the Brabantia corkscrew was not just a PTFE layer, but was hard nickel with PTFE particles in it. The judge's opinion here was that even in that situation the PTFE could be stated to be 'bonded to' the helix.

More interesting than this word-play was the discussion of the validity of the claims. According to Brabantia, the invention was too obvious to be patentable. The criterion for Judge Aldous, derived from previous cases, was whether or not the combination of the self-puller principle and the PTFE coating of the helix was obvious to 'any person skilled in the art'. From earlier self-puller corkscrew patents $[14,15]$ and existing self-puller corkscrews (such as the Japanese Nagai), and the fact that there already were other types of corkscrew to which the friction-reducing coating had been applied (e.g. the Sanbri twin-lever type) as well as other well-known applications of PTFE as a friction-reducing material, the judge concluded that it would be obvious to 'any person skilled in the art' that the PTFE coating should be chosen to reduce the friction of a self-puller corkscrew. Hallen claimed that the commercial success (one of the generally accepted valid arguments for a patent claim) of the Screwpull had shown that if the patent was really obvious, there should have been other persons who would have started producing this type of improved self-puller corkscrew. Even two experts in this field, Kraus and Babbage [16], had advised improvement of the twin-lever type rather than of the self-puller type. The judge, however, pointed out that this commercial success was only partially due to the patent because in one of the claims it was stated that the coating should be on the downwardly directed side of the helix, so that the frictionreducing effect would only function for inserting the helix into the cork and not for extracting the cork from the bottle (when the friction is along the upwardly directed side of the helix). As stated earlier, this point had already been mentioned very early in the process.
The final judgement was rather surprising: although the judge was of the opinion that the separate claims were obvious, the combination of Claims 1, 8, 9 and 10 was not obvious, and he allowed the patent to be amended to make this combination.

On the one hand the result was positive for Brabantia as the Hallen patent was found to be only partially valid and therefore the company was relieved from infringement to a large extent. An appeal by the plaintiff, Hallen Company, only resulted in a confirmation of this judgement by Judges Slade and Taylor on 17 October 1990 [17]. On the other hand, the new, amended Hallen patent would prevent the Brabantia corkscrew from being sold in the UK. This was a serious problem. We have already seen that Brabantia had recognized the potential of its corkscrew because of its favourable combination of scientific/ technological factors (the clever use of the combination of the self-puller principle and the frictionreducing properties of the PTFE coating) and market/aesthetic factors (the design fulfilled all the requirements that were found in the market research), as well as the fact that the Screwpull had proved the market potential of such a corkscrew. Therefore Brabantia realized the importance of finding a way to adapt the design so that the juridical factor (the Screwpull patent) would no longer be problematic, without losing the advantage of this good combination of the factors. This seemed to be the logical next step in the piecemeal rationality that guides the chain of corkscrew designs.

Brabantia chose an experience-based approach to find a solution to this problem. One way of avoiding infringement of the new patent was to change the length of the guide means. Trials on one of the existing Brabantia corkscrew designs reduced this length to about half its original value and the corkscrew functioned no worse than before [18]. ${ }^{10}$ The Brabantia design was thus adapted by simply reducing the length of the guide means by about $50 \%$ (Fig. 3). The revised corkscrew was brought onto the UK market and was a commercial success compared to the more expensive Screwpull, as Brabantia had expected. 


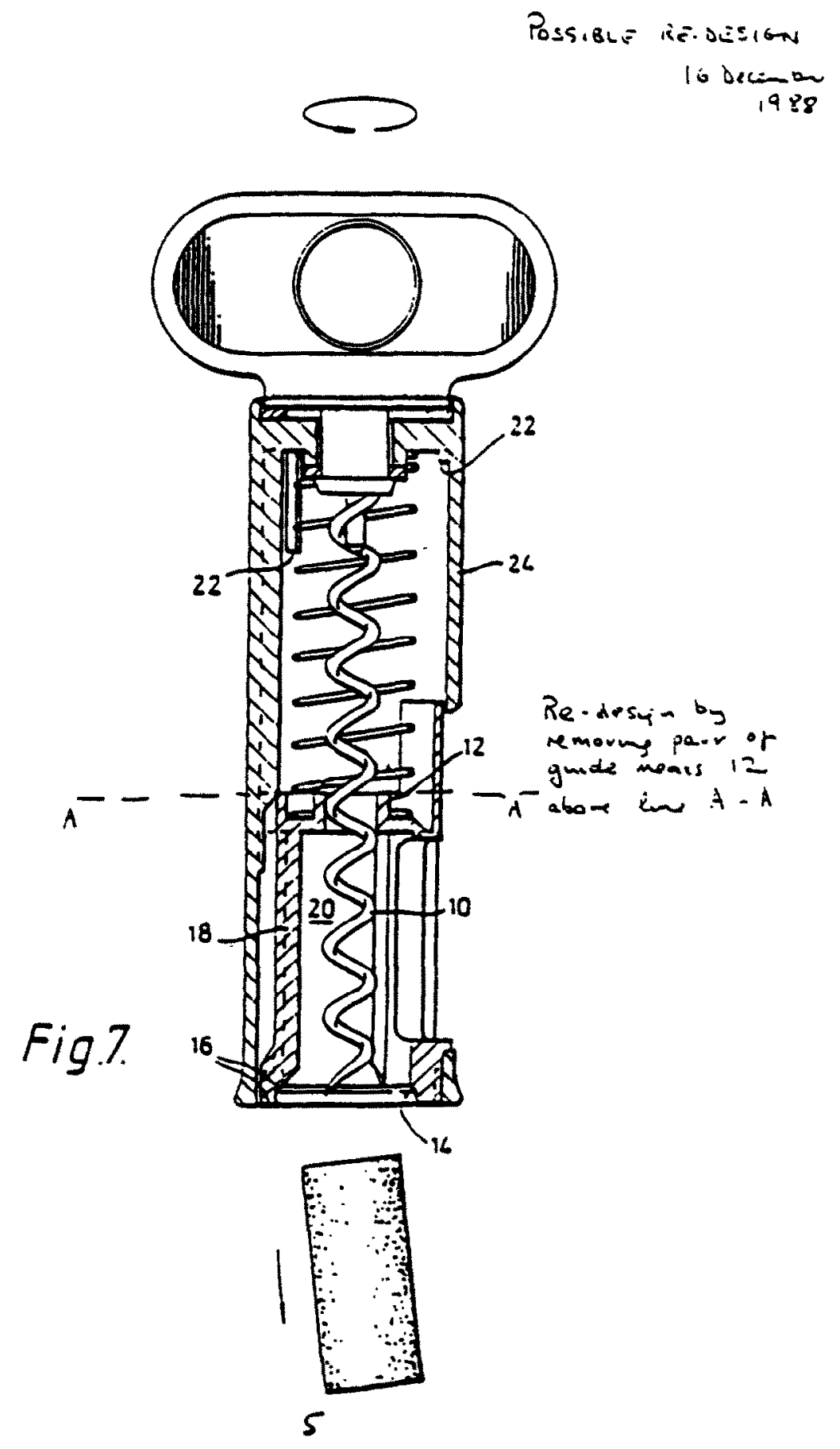

Fig. 3. The redesigned Brabantia corkscrew. 


\section{Conclusions}

What does the history of the Brabantia corkscrew design tell us about the way Brabantia took into account the various factors that were relevant for the development of the corkscrew? That was the question we stated in the introduction. Can we recognize a piecemeal rationality in the firm's approach?

The Brabantia corkscrew case is similar to the Plumbicon television pickup tube case that we described elsewhere [5] in that both companies recognized the potential of a design that provided a nice fit to a combination of scientific, technological, market and political/juridical factors. In the Plumbicon case there was a predecessor (the vidicon, a pickup tube that had been developed by RCA, a competitive company in the USA) that was almost perfect, but which needed a technological change (new target material). In the case of the Brabantia corkscrew, the Screwpull was the almost perfect predecessor that needed further development in marketing and aesthetic appeal (hiding the sharp helix point for safety, and the addition of a foil cutter and a cork-ejecting mechanism).

As in the Plumbicon case, we can see a piecemeal rationality: a potentially successful design is adapted to make it fit better with the factors as they are seen at a certain moment. Later the design is changed according to new requirements that follow from a changed combination of those factors: the Brabantia corkscrew is slightly adapted to fit the new patent situation (a juridical factor), although the change in design would not have made sense in the old situation.

The way a simple but clever solution was found to avoid infringement of the new Screwpull patent shows that this case is an example of an experiencebased technology: no theory about the forces that work in the guide means was tested in order to get a solution, but only simple experimentation by changing its length. Here the corkscrew case clearly deviates from the Plumbicon case, where years of fundamental research into the semiconductor properties of materials were necessary to reach the new design that fitted the new combination of factors.

The Brabantia corkscrew is thus another case that shows the importance of a clever analysis of the scientific, technological and social factors that influence the design process in a piecemeal rationality. Management decisions based on changes in only one of the factors (the discovery of a new material or the opening of a new market) without considering the whole combination of factors lead to decisions that yield unsuccessful designs, because they fit only some of the requirements that are determined by all factors together.

The case also shows how problematic the patent can be as a juridical factor in an experience-based technology. Anything that is obvious to 'any person skilled in the art' is not patentable, but this level of skill is the driving factor behind an experiencebased technological design. This would imply that patenting experience-based technologies is not simple. This is confirmed by Brabantia's experience in other designs [19]. Several years of working on new designs in the recent past have only resulted in one patent ${ }^{11}$. It would be an interesting field for further research to see whether this conclusion holds for other types of experience-based technology as well.

\section{Acknowledgements}

The author thanks Mr Cees van Elderen and Mr Martin Verhoeven of Brabantia for their kind cooperation in providing information and materials, and Prof. Dr Andries Sarlemijn and Dr Ir Peter Kroes for commenting on an earlier version of the manuscript.

\section{Notes}

${ }^{1}$ The Brabantia Group comprises two holding compa-
nies named Brabantia Holding BV and Brabantia
Valkenswaard BV (Valkenswaard is a Dutch village
near Eindhoven, where one of the Brabantia factories
is located). Brabantia Holding BV owns all companies 
within the Brabantia Group whose business is carried out in the Netherlands; Brabantia Valkenswaard is the holding company of the companies situated outside the Netherlands. One of these companies is Brabantia UK Ltd.

${ }^{2}$ Brabantia is owned by members of the Van Elderen family.

${ }^{3}$ This type of analysis is different from more traditional analyses of design methodology that focus on the steps in the design process. The empirical validity of such steps has become problematic since observational research in design methodology has shown that in practice the design process is too complex to describe in terms of such steps. Contrary to this traditional approach, the STeMPJE approach focusses on the various types of factor that determine the characteristics of a design. This approach and case studies that illustrate it are described in refs [4-6].

${ }^{4}$ The difference between these three types can be described as follows: experience-based technologies use knowledge that is no more than a collection of systematically acquired practical data on, e.g., material properties; macrotechnologies use more fundamental theories on macroscopic-level phenomena, such as thermodynamics or electrodynamics, in order to improve existing designs; in microtechnological developments, fundamental theories of microstructures are indispensable for the design. The gap between design reality and idealized theory increases from experience-based technologies to macrotechnologies to microtechnologies.

5 The concept of 'piecemeal rationality' is described [5 (p. 123)] as follows: "Planning is concerned with intermediate steps. After each step an inventory is taken of the present situation, with all its remaining uncertainties and newly gained knowledge. The transition from one design to the next requires a combination of . . . S- and T-factors with . . M- and P/J-factors. It is then possible to reformulate the set of requirements." The concept of piecemeal rationality is an alternative to the (according to Sarlemijn and de Vries) naive idea that there is a clear once-and-for-all rationality from the very beginning to the end of a chain of designs. Piecemeal rationality on the one hand means a kind of overall stability of the design chain (e.g. the global idea of what a corkscrew design should look like does not change very dramatically), but on the other hand the steps are based on circumstances that could not have been foreseen at the beginning of the chain, which gives a sort of fragmentation in the chain.

${ }^{6}$ Extensive descriptions of the various types are given by Watney and Babbage [7], and de Waard describes their mechanical aspects [8]. In de Waard's article the Brabantia corkscrew is mentioned as a successful corkscrew with good mechanical properties.

${ }^{7}$ There are some other types: one that has two thin legs that are forced in between the bottle neck and the cork, and another that pressurizes the space between the wine and the cork by inserting air.

${ }^{8}$ The Brabantia was a serious threat to the Hallen company because the Screwpull was its only product on the UK market (see [9]).

9 These points were described in more detail in the 'Plaintiff's Request for Admission' (19 June 1987) and admitted by the defendants ('Defendants' Admissions', 9 August 1987).

${ }^{10}$ This solution had already been mentioned in a letter by J.P.M. Allcock (Bristow, Cooke and Carpmael, Brabantia's patent officers) to J. Lennon (Brabantia UK) dated 20 December 1988.

11 This was for a pedal bin that had a small opening between the lid and the bin. This caused an air cushion to form when the lid dropped, thus preventing the lid from falling too hard on the bin.

\section{References}

1 C.H.J. van Elderen, Affidavit, April 1988.

2 M.P. Verhoeven, Affidavit, October 1988.

3 C.H.J. van Elderen and M.P. Verhoeven, personal communication, 1993.

4 A. Sarlemijn, Designs as cultural alloys. The STeMPJE approach in design methodology. In: M.J. de Vries, N. Cross and D.P. Grant (eds.), Design Methodology and Relationships with Science. Kluwer, Dordrecht, 1993.

5 A. Sarlemijn and M.J. de Vries, The piecemeal rationality of application-oriented research. An analysis of the R\&D history of the Plumbicon in the Philips research laboratories. In: P.A. Kroes and M. Bakker (eds.), Technological Development and Science in the Industrial Age. New Perpsectives on the Science-Technology Relationship. Reidel, Dordrecht, 1992.

6 M.J. de Vries, The Philips Stirling engine development. A historical-methodological case study into design process dynamics. Methodology and Science, 26(2) (1993) 74-86.

7 B.M. Watney and H.D. Babbage, Corkscrews for 
Collectors. Sotheby Parke Bernet, London and New York, 1981.

8 H. de Waard, De fysica van de kurketrekker. NRC Handelsblad, Scientific Supplement, 3 October 1985, p. 1.

9 H. Allen, Affidavit, April 1988.

10 G.Y. Bertin and S. Wyatt, Multinationals and Industrial Property. The Control of the World's Technology. Humanities Press, Atlantic Highlands, NJ, 1988.

11 P.C. Allam, Affidavit, March 1987.

12 J.R.A.M. Cheyne, Affidavit, April 1987.

13 M. Fysh (ed.), Reports of Patent Design and Trade Mark Cases [1989], No. 11. The Patent Office, London, 1989.

14 Chinnock, US Patent No. 35 362, 1862.

15 Baumgarten, UK Patent, 1902.

16 H. Kraus and H.D. Babbage, Symptoms of withdrawal. An assessment of mechanical corkscrews. Communications of Mechanical Engineering (December 1977), 70-75.
17 R. Davies, Corkscrew advance was obvious. FT law reports. Financial Times, Wednesday 24 October 1990.

18 M.P. Verhoeven, personal communication, 1991.

19 C.H.J. van Elderen, personal communication, 1992.

Marc J. de Vries (MSc, Free University Amsterdam, 1982; $\mathrm{PhD}$, Eindhoven University of Technology, 1988) was educated as a physicist. From 1988 to 1992 he was responsible for the Technology Education Department of the Pedagogical Technological College in Eindhoven, The Netherlands. Since 1990 he has been Assistant Professor in the Philosophy and Methodology of Technology at the Eindhoven University of Technology (Faculty of Philosophy and Social Sciences), and in particular be is concerned with research in the field of design methodology. He organized an international conference on 'Design Methodology and Relationships with Science' for NATO, and was editor of the proceedings of this conference, which were published by Kluwer Academic Publishers. He has several other publications on technology education and design methodology in professional journals and conference proceedings. 